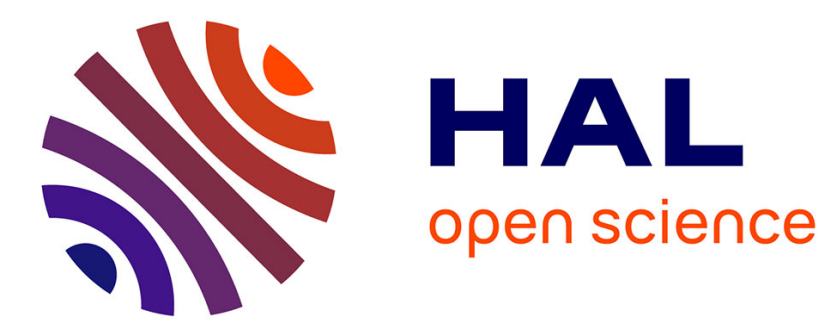

\title{
Continuous screening system for inhibited enzyme catalysis: A membrane reactor approach
}

Evgenij Lyagin, Anja Drews, Subhamoy Bhattacharya, Marion Bettina Ansorge-Schumacher, Matthias Kraume

\section{- To cite this version:}

Evgenij Lyagin, Anja Drews, Subhamoy Bhattacharya, Marion Bettina Ansorge-Schumacher, Matthias Kraume. Continuous screening system for inhibited enzyme catalysis: A membrane reactor approach. Biotechnology Journal, 2010, 5 (8), pp.813. 10.1002/biot.201000130 . hal-00560296

\section{HAL Id: hal-00560296 https://hal.science/hal-00560296}

Submitted on 28 Jan 2011

HAL is a multi-disciplinary open access archive for the deposit and dissemination of scientific research documents, whether they are published or not. The documents may come from teaching and research institutions in France or abroad, or from public or private research centers.
L'archive ouverte pluridisciplinaire HAL, est destinée au dépôt et à la diffusion de documents scientifiques de niveau recherche, publiés ou non, émanant des établissements d'enseignement et de recherche français ou étrangers, des laboratoires publics ou privés. 


\section{Continuous screening system for inhibited enzyme catalysis: A membrane reactor approach}

\begin{tabular}{|c|c|}
\hline Journal: & Biotechnology Journal \\
\hline Manuscript ID: & biot.201000130.R2 \\
\hline Wiley - Manuscript type: & Research Article \\
\hline $\begin{array}{r}\text { Date Submitted by the } \\
\text { Author: }\end{array}$ & 03-Jul-2010 \\
\hline Complete List of Authors: & $\begin{array}{l}\text { Lyagin, Evgenij; Technische Universität Berlin, Chair of Chemical } \\
\text { and Process Engineering } \\
\text { Drews, Anja; HTW Berlin, Dept. of Engineering II } \\
\text { Bhattacharya, Subhamoy; Technische Universität Berlin, Chair of } \\
\text { Chemical and Process Engineering/Dept. of Enzyme Technology } \\
\text { Ansorge-Schumacher, Marion; Technische Universität Berlin, Inst. } \\
\text { of Chemistry, Dept. of Enzyme Technology } \\
\text { Kraume, Matthias; Technische Universität Berlin, Chair of Chemical } \\
\text { and Process Engineering }\end{array}$ \\
\hline Primary Keywords: & Biocatalysis \\
\hline Secondary Keywords: & Screening \\
\hline Keywords: & $\begin{array}{l}\text { Screening system, Enzyme membrane reactor, Membrane } \\
\text { continuous stirred tank reactor }\end{array}$ \\
\hline
\end{tabular}

\section{s ScholaroNE" \\ Manuscript Central}




\title{
Research Article \\ Continuous screening system for inhibited enzyme catalysis: A membrane reactor approach
}

Evgenij Lyagin $^{1 *}$, Anja Drews ${ }^{2}$, Subhamoy Bhattacharya ${ }^{1,3}$, Marion B. Ansorge-Schumacher ${ }^{3}$, Matthias Kraume ${ }^{1}$

* Corresponding author, Tel.: +49 30 31472693, Fax: +49 30 31472756, e-mail:

evgenij.lyagin@tu-berlin.de

${ }^{1}$ Technische Universität Berlin, Chair of Chemical and Process Engineering, Sekr. MA 5-7, Straße des 17. Juni 135, 10623 Berlin, Germany

${ }^{2}$ HTW Berlin, Dept. of Engineering II, School of Life Science Engineering, Wilhelminenhofstr. 75a, 12459 Berlin, Germany

${ }^{3}$ Technische Universität Berlin, Institute of Chemistry, Department of Enzyme Technology, Sekr. TC 4, Straße des 17. Juni 124, 10623 Berlin, Germany

\section{Keywords:}

Screening system, enzyme membrane reactor, membrane continuous stirred tank reactor, cellulose hydrolysis, feedback control

\begin{abstract}
Abbreviations:
HTS, High-throughput screening; MTP, Microtitre plate; STR, Stirred tank reactor; CSTR, Continuous stirred tank reactor; MCSTR, Membrane continuous stirred tank reactor; DO, dissolved oxygen; OD, optical density
\end{abstract}


The screening of catalysts, substrates or conditions in the early stages of bioprocess development requires an enormous number of experiments and is a tedious, expensive and time consuming task. Currently available screening systems can only be operated in batch or fed-batch mode which can lead to severe misinterpretations of screening results. For example, catalysts that are inhibited by substrates or accumulating products will be excluded from further investigations in the early stages of process development despite the fact that they might be superior to other candidates in a different operational mode. Important and advantageous properties such as turnover stability can also be overshadowed by product inhibition. The aim of this study is to develop a novel screening system which enables continuous feeding of substrates and continuous removal of products. A prototype based on the membrane reactor concept was designed and operated for a model reaction, the hydrolysis of cellulose. 


\section{Introduction}

\subsection{State of the art}

The search for a suited biocatalyst, its optimum conditions and substrates or novel products is the first step in each bioprocess development. This is typically achieved in a large number of parallel experiments in micro- to millilitre scale (high-throughput screening, HTS). This high degree of parallelism, however, is achieved at the cost of largely uncontrolled process operation. Although sometimes very large scale-up ratios are used during the development of new biotechnological processes, a scale-up ratio of about 1:10 is taken as the upper acceptable limit $[1,2]$. The following four scales are typically mentioned: $50-1000 \mathrm{~mL}$ (shake-flasks scale), 5-20 L (bench scale), 50-5000 L (pilot plant scale) and 10-1000 $\mathrm{m}^{3}$ (production scale) [1]. Shake flasks are used typically for experiments in the scale up to $1000 \mathrm{~mL}$. Such experiments are quite inexpensive and simple, however significant problems like insufficient oxygen supply, inefficient mixing or inability to continuously monitor them are often mentioned [3]. For this reason many producers as well as research groups attempt to develop new screening systems, which are able to overcome the given drawbacks. Table 1 summarises commercially available and recently developed screenings systems (above MTP scale) up to bench scale. The main focus is on STR based screening systems which are typically favoured for secondary screening, since the large majority of industrial fermentations is carried out in stirred bioreactors.

As seen above, currently available systems can mainly be operated in batch or fed-batch mode, which especially for inhibited reactions can lead to severe misinterpretations of screening results. For example, catalysts that are inhibited by accumulating products or high initial substrate concentrations will be excluded from further investigations in the early stage of process design, despite the fact that they might be superior to other candidates when operated in a different mode. Some attempts have been made to develop continuous screening 
reactors [4], but such systems do not contain a filtration module so application is limited to whole cell transformations and immobilised enzymes. However, this problem can be eliminated by using an ultrafiltration membrane which retains dissolved enzymes. This project thus aims at developing a novel screening system which enables continuous feeding of substrates and continuous removal of products. It will thus, e.g., reduce the amount of unwanted by-products, or increase product yield or reaction rate. In addition, important process parameters like residence time and volumetric power input shall be determined and feed-back controlled if required to facilitate safe scale-up of results to bench-scale. Table 2 gives a survey of commercially available and developed membrane-based reactor systems for enzymatic reactions.

Although a lot of membrane-based reactor systems have been developed, to our knowledge only one attempt was made to bring to market an enzyme membrane reactor with continuous operation mode. Unfortunately this system is not available anymore, since the company (Jülich Fine Chemicals GmbH) seized to exist in 2005. Common for all developed systems is that they do not work in parallel. Also, often the main parameters like residence time or $\mathrm{pH}$ are not controlled. Another aspect is the costs of developed systems, which even for small scale EMR could be quite high [12]. The systems which are summarised in Table 2 can be divided into 3 categories according to the form of substrate-enzyme contact [29]: those with direct S-E contact, those with indirect S-E contact and two-phase membrane reactors. Fig. 1 shows typical designs for each category.

From the above it is obvious that the membrane can fulfil very different tasks: it can be used to separate the enzyme from the product (A), for bubble free aeration $(\mathrm{C})$, provide a contact surface/interface for two-phase mass transfer (E), etc. No single system can satisfy all needs and a compromise between functionality or versatility and economics has to be made. Thus, this work initially focuses on direct S-E contact applications. 
1.2 Design of a novel screening system for potentially inhibited biocatalysis

With regards to the mentioned shortcomings of currently available systems, the following requirements were specified. The novel concept must:

- be suited for non-immobilised enzymes

- not exceed a working volume of $100 \mathrm{~mL}$

- enable scale-up to bench-scale

- enable monitoring and control of: T, $\mathrm{pH}, \mathrm{DO}, \mathrm{OD}$, Redox and residence time $\tau$

- enable parallel operation of several reactors $(>2)$

- be low priced

Besides monitoring and if possible feed-back control of $\mathrm{pH}$, temperature, etc., the main parameter that needs to be reliably controlled in a continuous MCSTR is residence time or, in other words, membrane permeability. Transmembrane flux and thus product removal can be achieved by either permeate suction or by pressure increase on the feed side. The former necessitates the use of an adjustable permeate pump, and the transmembrane pressure is limited to 1 bar atmospheric pressure which might not be enough to ensure a satisfactory flux throughout the duration of the process. In the latter option, no permeate pump but a control valve and a pressure source are required, and higher transmembrane pressures can be utilised. This, on the other hand, necessitates the use of pressure resistant sensors and equipment. In order to maintain the required membrane permeability, the formation of deposits on the membrane surface must be limited. This can be achieved by shear and lift forces, e.g. either accomplished in external cross-flow filtration or by rotating devices close to the surface. External filtration requires an additional pump and provides a larger surface onto which enzymes, substrate and products can adsorb, hence, in-situ filtration was selected. Fig. 2 shows P\&I diagrams of two such in-situ MCSTRs in which permeation is achieved by increased feed pressure. If oxygen is required for the reaction, option A must be used, while option B will suffice in all other cases. Since less than $20 \%$ of industrial applications use 
oxidoreductases [30], option B is chosen for this study. Feedback control of the residence time is achieved by monitoring the flow rate and adjusting the feed pressure.

\subsection{Choice of a suited model reaction}

For a first feasibility study of the reactor concept, a model reaction is applied. It was decided to use a hydrolysis since $72 \%$ of industrial enzyme catalysis is performed with hydrolases [30]. The hydrolysis of cellulose was found to be particularly suited for the proof of concept of the continuous screening system since:

- the reaction is well known and described

- it is widely applied in the industries of the energy sector, food and chemicals [31]

- it is strongly inhibited by its products

- it cannot be performed with immobilised enzymes

The latter two render the use of an MCSTR an attractive option. The reaction proceeds in four steps (see. Fig. 3). Its products glucose and cellobiose strongly inhibit the last two steps. While cellobiose inhibition can be reduced by the addition of further cellobiase (i.e. $\beta$ glucosidase), this enzyme itself is inhibited by the presence of glucose, which can only be prevented by in-situ product removal [32].

\section{Materials and methods}

2.1 Implementation of the screening system

The main components are: the membrane reactor, a mixing device, a thermostat, a control valve and a flow meter. Two stirred dead-end cells (XFUF-047, Millipore Corporation) with a working volume of $86 / 89,8 \mathrm{~mL}$ (batch/continuous) and a diameter of $47 \mathrm{~mm}$ were used as the membrane reactors. A flat-sheet membrane (eff. surface $14.7 \mathrm{~cm}^{2}$ ) is placed at the bottom. With this surface to volume ratio, residence times in the range of 2-24 $\mathrm{h}$ can be realised assuming typical fluxes between $2.5-30 \mathrm{~L} /\left(\mathrm{m}^{2} \mathrm{~h}\right)$. The cell is mixed by a magnetic stirrer $(2$ 
MAG MIX 1) that enables accurate stirrer speed control in the range between 100 bis 2000 $\min ^{-1}$. Retentate pressure was controlled with a pressure regulator (MPPE-3, Festo AG, \pm 20 mbar accuracy). The MCSTRs were placed in a water bath that was temperature controlled (thermostat D1, Thermo Haake GmbH). An electronic precision balance (ALT 310, Kern \& Sohn $\mathrm{GmbH}$ ) was used to measure the permeate flow. Data were logged onto a computer with a frequency of $4 \mathrm{~Hz}$. To enable robust control, values were averaged over $25 \mathrm{~s}$ (100 values). The use of a volumetric flow meter would be advantageous because of robustness, unlimited operation time, and simpler integration into a parallel reactor set-up, but flow meters in the required low measuring range of around $5 \mathrm{~mL} / \mathrm{h}$ are about twice as expensive. They would, however, just change the controller settings and not the idea of the control scheme (see 3.1). $\mathrm{pH}$ was measured in the permeate. Visual Designer ${ }^{\mathrm{TM}}$ (Version 4.0) was used to modulate and optimise the PI/PID controller settings.

2.2 Choice of enzyme, substrate and membrane Cellulase from Trichoderma reesei (Sigma-Aldrich, C8546) was used. This enzyme contains three constituents: exocellulase, endocellulase and $\beta$-glucosidase (cellobiase). Their molecular weight can range from 23-105 kDa [34]. Hence, an ultrafiltration membrane with a MWCO of $10 \mathrm{kDa}$ (UP010, PES, Microdyn-Nadir GmbH, Germany) was used to retain the enzymeconsortium. Even a membrane with a higher MWCO of $30 \mathrm{kDa}$ was shown to retain around $90 \% \beta$-Xylanase (MW $20 \mathrm{kDa},[35]$ ). The molecular weight of the products is 180 and $342 \mathrm{Da}$, respectively, so it is safe to assume that the products pass the membrane unhindered. $\alpha$-cellulose (Sigma-Aldrich, C8002) is used as the substrate.

\subsection{Analytical methods}

The surrogate concentration of reduced sugars was measured using refractometry (DD-7, precision $\pm 0.005 \%$ [Brix], ATAGO Co., Ltd.) which was calibrated with a glucose standard. 
From this concentration, cellulose conversion was calculated. Samples were taken from the permeate.

\subsection{Enzyme activity}

The required amount of enzymes was dosed in units/L. Here, one unit was defined as the amount of enzymes that is required to yield $1 \mu \mathrm{mol} / \mathrm{h}$ glucose from cellulose at $\mathrm{T}=37^{\circ} \mathrm{C}$ and $\mathrm{pH}=5$ over a period of $2 \mathrm{~h}$. Enzyme activity was performed in accordance with the SigmaAldrich Control Test Procedure [36].

\section{Results and Discussion}

\subsection{Feedback Control Concept}

Residence time, i.e. flow rate control is carried out with the feed pressure as the actuating variable. Since the systems' response to a step change showed a typical $\mathrm{PT}_{\mathrm{n}}$-behaviour, closed-loop control could be achieved with a PI or PID controller. Therefore, the system response was initially approximated with $\mathrm{PT}_{1} \mathrm{~T}_{0}$ and $\mathrm{PT}_{\mathrm{n}}$ models. Different settings according to Ziegler and Nichols [37], Kuhn [38], Chien et al. [39] and Schwarze [40] were then assessed with respect to their disturbance reaction. Fig. 4 shows an example of this procedure for Kuhn [38] settings. During the first 200 s, the system was not controlled and the curve just represents the system response. Feedback control is then switched on, and the emerging curve is a measure of the set value behaviour. After $670 \mathrm{~s}$, a defined and reproducible disturbance was induced and again the system response evaluated. Thus, an evaluation of different controller settings could be performed. The comparison between different controller settings showed for example, that with the settings according to Ziegler and Nichols [37] as well as Chien et al. [39] the system responded well to disturbances, but it takes a long time to reach the set values. It could also be detected, that in all cases the PID settings led to faster attainment of the set values. However, when disturbances were introduced, the fluctuations 
and the time required to attain the set values were minimised when PI settings were used. After the comparison of different PI settings according to Ziegler and Nichols [37], Kuhn [38], Chien et al. [39] and Schwarze [40], the settings according to Kuhn [38] were found to be the best in terms of their disturbance behaviour and set values behaviour. For all following experiments these settings were used.

Fig. 5 shows results of a long-term study which should primarily prove the control concept's ability to keep the flow and thus the residence time at the desired value (e.g. $10 \mathrm{~mL} / \mathrm{h}$ and $9 \mathrm{~h}$, respectively) with an acceptable accuracy over a longer period and with potential membrane fouling.

As can be seen from Fig. 5, a stable flow and thus residence time feedback control could be implemented using controller settings acc. to Kuhn. The volumetric flow rate was $9.998 \mathrm{~mL} / \mathrm{h}$ on average over $20 \mathrm{~h}$ and a standard deviation value of $0.228 \mathrm{~mL} / \mathrm{h}$ was calculated based on the assumption of a Gaussian distribution of the data shown in figure 5. The pressure increase after approximately 16 hours can be explained by membrane fouling (e.g. successive closure of pores until the local flux exceeds the critical flux) which occurs during filtration of biological suspensions even under cross-flow conditions, i.e. continuous removal of accumulations from the membrane surface [41]. Visual inspection showed that the deposit, however, was so small that the homogeneity of the reactor content was not affected.

\subsection{Parallel Batch Operation}

Fig. 6 shows results of two parallel batch experiments. The hydrolysis was carried out at a temperature of $40^{\circ} \mathrm{C}$ with a sodium acetate buffer $(\mathrm{pH}=4.66)$. These conditions were selected according to manufacturer's recommendations which do not mean that they are necessarily optimal. Enzyme concentration used was $200 \mathrm{mg} / \mathrm{L}$ (measured enzyme activity was $5.6 \mathrm{u} / \mathrm{mg}$ ) which enabled comparison with published results. $2 \mathrm{~mL}$ samples were taken from the permeate and immediately returned after analysis in order to keep the reactor volume and 
enzyme concentration constant. Conversion was calculated under the assumption of an ideally mixed reactor (Eq. 1):

$$
\text { Conversion }(t)=\frac{c_{\text {Sample }}(t)}{c_{S, 0}} \cdot 100 \%
$$

It can be seen that there is a good fit between the obtained data and the data published, measured under identical conditions, despite the fact that enzyme concentration cannot be compared exactly since dosing in Gan et al. [28] was done in $\mathrm{mg} / \mathrm{L}(200 \mathrm{mg} / \mathrm{L})$ and the enzyme activity was not mentioned. Because a similar time dependent conversion was observed for the same concentration, it may be stated that the activity of our enzyme was comparable to that of Gan's. Fig. 6 also shows the parallelism of both reactors. Deviations are less than $8 \%$ (to the averaged values) at all times. Possible reasons for the decreasing rate of conversion include substrate depletion, product inhibition and enzyme deactivation. Gan et al. [28], too, observed such a decrease although the data chosen for comparison here almost suggest a linear progress.

\subsection{Continuous vs. Batch Operation}

Fig. 7 shows a comparison of cellulose conversion in batch and continuous mode under otherwise equivalent conditions (enzyme and substrate concentration, temperature, $\mathrm{pH}$, power input). In continuous operation, the insoluble substrate and enzymes were added to the reactor only at the beginning. Then buffer was added continuously and product solution withdrawn at the same rate during the entire reaction period. The hydrolysed sugars were removed from the reactor while substrate and enzymes were retained. The desired residence time of $6 \mathrm{~h}$ was controlled with an accuracy of $\pm 1 \%$ over the whole duration of the experiment (data not 
showed). Similar to the batch operation, the conversion was calculated under the assumption of an ideally mixed reactor (Eq. 2):

$$
\text { Conversion }(t)=\frac{V_{\text {Collected }}(t) \cdot \bar{c}(t)+V_{\text {Sample }} \cdot c_{\text {Sample }}(t)+V_{\text {Reactor }} \cdot c_{\text {Sample }}(t)}{V_{\text {Reactor }} \cdot c_{S, 0}} \cdot 100 \%
$$

With a deviation of $<2.5 \%$ (to the averaged values), the reproducibility of continuous experiments is very high. It is obvious that continuous operation increases cellulose conversion and reaction rate by around $60 \%$ in comparison to batch. After 60 h, $70.6 \%$ of the initially provided substrate have been converted in the continuous run, while at the same time, only $43.5 \%$ were achieved in batch mode. Or, in other words, to reach the same conversion, an increased reaction time is required (already more than doubled for $40 \%$ conversion). Since all operating conditions were the same, this increase in reaction rate can only be attributed to the product inhibition that dominates in the batch run. However, since reaction rate depends on substrate concentration, conversion slows down in the continuous mode, too.

Fig. 8. shows the corresponding product concentration evolution for Fig. 7 in continuous and batch operation mode. Clearly, the reaction inhibition in case of batch operation is strongly pronounced due to the high concentration of glucose and cellobiose (which is 11 times higher than in continuous operation after $60 \mathrm{~h}$ ). In the case of continuous mode, operation at a constant residence time decreases product concentration. This also indicates one of the biggest drawbacks of continuous operation: in production processes, the product concentration in the permeate flow could be too low for directly further usage, e.g. for ethanol production, a glucose concentration between 8 and $10 \%$ has been suggested [31]. In comparison with published data, a significantly higher yield was achieved here. The residence time was not given, but under otherwise similar conditions, Gan et al. [28] had 
reached max. $53 \%$ after $48 \mathrm{~h}$ of continuous operation, while in this work, $63.5 \%$ were obtained (see Fig. 7).

\section{Concluding remarks}

Currently available screening systems have several drawbacks, e.g. the fact that they cannot be operated continuously. In order to release the potential of possibly product inhibited catalysts, a screening reactor concept based on a membrane CSTR was conceived and constructed. The concept's potential was shown using the enzymatic hydrolysis of cellulose as a model reaction. In this feasibility study, some imperative key features were attested: The novel system (1) enables screening of product or substrate inhibited enzymes which would have been excluded from future studies in normal (batch) screening systems, (2) can be operated at a controlled residence time ( $\pm 1 \%$ accuracy), (3) shows good agreement in parallel experiments, and (4) yields reproducible results.

\section{Acknowledgements}

This work is part of the Cluster of Excellence "Unifying Concepts in Catalysis" coordinated by the Technische Universität Berlin. Financial support by the Deutsche Forschungsgemeinschaft (DFG) within the framework of the German Initiative for Excellence is gratefully acknowledged (EXC 314).

The authors have declared no conflict of interest.

\section{List of symbols}

Flow rate $\left[\mathrm{m}^{3} / \mathrm{s}\right]$

P Pressure $\quad[\mathrm{Pa}]$

T Temperature $\quad[\mathrm{K}]$ 
Residence time

[s]

n

Rotation speed

$\left[\mathrm{s}^{-1}\right]$

c

Concentration

$\left[\mathrm{kg} / \mathrm{m}^{3}\right]$

V

Volume

$\left[\mathrm{m}^{3}\right]$

\section{Subscripts}

Substrate

E

Enzyme

0

Initial 


\section{References}

[1] Votruba, J., Sobotka, M., Physiological Similarity and Bioreactor Scale-up. Folia Microbiol. 1992, 37, 331-345.

[2] Garcia-Ochoa, F., Gomez, E., Bioreactor scale-up and oxygen transfer rate in microbial processes: An overview. Biotechnol. Adv. 2009, 27, 153-176.

[3] Büchs, J., Introduction to advantages and problems of shaken cultures. Biochem. Eng. J. 2001, 7, 91-98.

[4] Akgun, A., Maier, B., Preis, D., Roth, B. et al., A novel parallel shaken bioreactor system for continuous operation. Biotechnol. Prog. 2004, 20, 1718-1724.

[5] Weuster-Botz, D., Altenbach-Rehm, J., Arnold, M., Parallel substrate feeding and pHcontrol in shaking-flasks. Biochem. Eng. J. 2001, 7, 163-170.

[6] Doig, S.D., Diep, A., Baganz, F., Characterisation of a novel miniaturised bubble column bioreactor for high throughput cell cultivation. Biochem. Eng. J. 2005, 23, 97-105. [7] Altenbach-Rehm, J., Nell, C., Arnold, M., Weuster-Botz, D., Parallel bubble columns with fed-batch technique for microbial process development on a small scale. Chem. Eng. Technol. 1999, 12, 1051-1058.

[8] Harms, P., Kostov, Y., French, J.A., Soliman, M. et al., Design and performance of a 24-station high throughput microbioreactor. Biotechnol. Bioeng. 2006, 93, 6-13.

[9] Kusterer, A., Krause, C., Kaufmann, K., Arnold, M. et al., Fully automated single-use stirred-tank bioreactors for parallel microbial cultivations. Bioprocess Biosyst. Eng. 2008, 31, 207-215.

[10] Ge, X., Hanson, M., Shen, H., Kostov, Y. et al., Validation of an optical sensor-based high-throughput bioreactor system for mammalian cell culture. J. Biotechnol. 2006, 122, 293306. 
[11] Gill, N.K., Appleton, M., Baganz, F., Lye, G.J., Design and characterisation of a miniature stirred bioreactor system for parallel microbial fermentations. Biochem. Eng. J. 2008, 39, 164-176.

[12] Müller, D.H., Liauw, M.A., Greiner, L., Microreaction technology in education: miniaturized enzyme membrane reactor. Chem. Eng. Technol. 2005, 28, 1569-1571.

[13] Bongs, J., Hahn, D., Schörken, U., Sprenger G.A. et al., Continuous production of erythrulose using transketolase in a membrane reactor. Biotechnol. Lett. 1997, 19, 213-215. [14] Hildebrand, F., Kühl, S., Pohl, M., Vasic-Racki, D. et al., The production of (R)-2hydroxy-1-phenyl-propan-1-one derivatives by benzaldehyde lyase from Pseudomonas fluorescens in a continuously operated membrane reactor. Biotechnol. Bioeng. 2007, 96, 835843.

[15] Habulin, M., Primozic, M., Knez, Z., Enzymatic reactions in high-pressure membrane reactors. Ing. Eng. Chem. Res. 2005, 44, 9619-9625.

[16] Greiner, L., Müller, D.H., Ban, E.C.D., Wöltinger, J. et al., Membrane aerated hydrogenation: Enzymatic and chemical homogeneous catalysis. Adv. Synth. Catal. 2003, $345,679-683$.

[17] Trusek-Holownia, A., Noworyta, A., An integrated process: Ester synthesis in an enzymatic membrane reactor and water sorption. J. Biotechnol. 2007, 130, 47-56.

[18] Bodalo, A., Gomez, J.L., Gomez, E., Bastida, J. et al., Ultrafiltration membrane reactors for enzymatic resolution of amino acids: design model and optimization. Enzyme Microb. Tech. 2001, 28, 355-361.

[19] Liese, A., Zelinski, T., Kula, M.-R., Kierkels, H. et al., A novel reactor concept for the enzymatic reduction of poorly soluble ketones. J. Mol. Catal. B-Enzym. 1998, 4, 91-99.

[20] Yang, S., Ding, W., Chen, H., Enzymatic hydrolysis of rice straw in a tubular reactor coupled with UF membrane. Process Biochem. 2006, 41, 721-725. 
[21] Kwon, S.J., Song, K.M., Hong, W.H., Rhee, J.S., Removal of water produced from lipase-catalyzed esterification in organic solvent by pervaporation. Biotechnol. Bioeng. 1995, 46, 393-395.

[22] Prazeres, D.M.F., Garcia, F.A.P., Cabral, J.M.S., Continuous lipolysis in a reverced micellar membrane beioreactor. Bioprocess Eng. 1994, 10, 21-27.

[23] Molinari, F., Aragozzini, F., Cabral, J.M.S., Prazeres, D.M.F., Continuous production of isovaleraldehyde through extractive bioconversion in a hollow-fiber membrane bioreactor. Enzyme Microb. Tech. 1997, 20, 604-611.

[24] Goulas, A.K., Cooper, J.M., Grandison, A.S., Rastall, R.A., Synthesis of isomaltooligosaccharides and oligodextrans in a recycle membrane bioreactor by the combined use of dextransucrase and dextranase. Biotechnol. Bioeng. 2004, 88, 778-787.

[25] Slominska, L., Szostek, A., Grzeskowiak, A., Studies on enzymatic continuous production of cyclodextrins in an ultrafiltration membrane bioreactor. Carbohyd. Polym. 2002, 50, 423-428.

[26] Guit, R.P.M., Kloosterman, M., Meindersma, G.W., Mayer, M. et al., Lipase kinetics: Hydrolysis of triacetin by lipase from Candida cylindracea in a hollow-fiber membrane reactor. Biotechnol. Bioeng. 1991, 38, 727-732.

[27] Martin-Orue, C., Henry, G., Bouhallab, S., Tryptic hydrolysis of kcaseinomacropeptide: Control of the enzymatic reaction in a continuous membrane reactor. Enzyme Microb. Technol. 1999, 24, 173-180.

[28] Gan, Q., Allen, S.J., Taylor, G., Design and operation of an integrated membrane reactor for enzymatic cellulose hydrolysis. Biochem. Eng. J. 2002, 12, 223-229.

[29] Prazeres, D.M.F., Cabral, J.M.S., Enzymatic Membrane Bioreactors and Their Applications. Enzyme Microb. Technol. 1994, 16, 738-750.

[30] Aehle, W., 2007. Enzymes in Industry, third ed. Willey-VCH Verlag, Weinheim 2007, pp. 257-262. 
[31] Ladisch, M.R., Lin, K.W., Voloch, M., Tsao, G.T., Process Considerations in the Enzymatic-Hydrolysis of Biomass. Enzyme Microb. Technol. 1983, 5, 82-102.

[32] Breuil, C., Chan, M., Gilbert, M., Saddler, J.N., Influence of Beta-Glucosidase on the Filter-Paper Activity and Hydrolysis of Lignocellulosic Substrates. Bioresour. Technol. 1992, $39,139-142$.

[33] Schurz, J., Billiani, J., Honel, A., Eigner, W.D. et al., Reaction-Mechanism and Structural-Changes at Enzymatic Degradation of Cellulose by Trichoderma-Reesei-Cellulase. Acta Polymerica, 1985, 36, 76-80.

[34] Miettinen-Oinonen, A., Trichoderma reesei strains for production of cellulases for the textile industry. VTT Publications 550, Espoo 2004, 18-21.

[35] Ehsani, N., Nyström, M., Ojamo, H., Siika-aho, M., Separation of Enzymes Produced by Trichoderma reesei with Hydrophobic Ultrafiltration Membranes. Process Biochem. 1996, $31,253-263$.

[36] Sigma-Aldrich Corporation, Enzymatic Assay of Cellulase (EC 3.2.1.4), control test procedure, 1995.

[37] Ziegler, J.G., Nichols, N.B., Optimum settings for automatic controllers. Trans. ASME $1942,64,759-768$.

[38] Kuhn, U., Eine praxisnahe Einstellregel für PID-Regler: Die T-Summen-Regel. Automatisierungstechnische Praxis, 1995, 5, 10-16.

[39] Chien, K.L., Hrones, J.A., Reswick, J.B., On the Automatic Control of Generalized Passive Systems. Transactions of the American Society of Mechanical Engineers Bd., 1952, $74,175-185$.

[40] Reuter, M., Zacher, S., Regelungstechnik für Ingenieure, twelfth ed. Vieweg + Teubner, Wiesbaden 2004, pp. 229-231.

[41] Le-Clech, P., Chen, V., Fane, A.G., Fouling in membrane bioreactors used in wastewater treatment. J. Membr. Sci. 2006, 284, 17-53. 
Figure 1: MCSTR configurations: A) with direct S-E contact and in-situ filtration; B) with direct S-E contact and external filtration; C) with direct S-E contact and membrane aeration; D) MCSTR with indirect S-E contact and external filtration (dialysis); E) two-phase MCSTR with external circulation (membrane contactor); •: enzyme; S: substrate; P: product; MC: Membrane Contactor; MAU: Membrane Aeration Unit

Figure 2: In-situ MCSTR concepts: A) with oxygen supply; B) without oxygen supply; • enzymes; ○ gas bubbles; S: substrate; P: product

Figure 3: Suggested reaction mechanism of cellulose hydrolysis with a cellulase complex; $\mathrm{C}_{1}$ : Exocellulase; $\mathrm{C}_{\mathrm{X}}$ : Endocellulase (adapted from [33])

Figure 4: Example of a step response: PI and PID controller acc. to Kuhn [38], set value and disturbance behaviour for different controller settings

Figure 5: Volumetric flow rate and retentate pressure development, $\mathrm{c}_{\mathrm{S}, 0}=25 \mathrm{~g} / \mathrm{L}, \mathrm{T}=40^{\circ} \mathrm{C}$ (PI controller acc. to Kuhn [38])

Figure 6: Cellulose conversion during parallel batch runs, $\mathrm{c}_{\mathrm{E}}=1120 \mathrm{U} / \mathrm{L}, \mathrm{c}_{\mathrm{S}, 0}=25 \mathrm{~g} / \mathrm{L}, \tau=6 \mathrm{~h}, \mathrm{~T}=40{ }^{\circ} \mathrm{C}, \mathrm{pH}=$ $4.66, \mathrm{n}=100 \mathrm{~min}^{-1}$

Figure 7: Cellulose conversion during batch and continuous operation, $\mathrm{c}_{\mathrm{E}}=1120 \mathrm{U} / \mathrm{L}, \mathrm{c}_{\mathrm{S}, 0}=25 \mathrm{~g} / \mathrm{L}, \tau=6 \mathrm{~h}, \mathrm{~T}=$ $40{ }^{\circ} \mathrm{C}, \mathrm{pH}=4.66, \mathrm{n}=100 \mathrm{~min}^{-1}$

Figure 8: Concentration profile for products (glucose and cellobiose) during batch and continuous operation, $\mathrm{c}_{\mathrm{E}}=$ $1120 \mathrm{U} / \mathrm{L}, \mathrm{c}_{\mathrm{S}, 0}=25 \mathrm{~g} / \mathrm{L}, \tau=6 \mathrm{~h}, \mathrm{~T}=40^{\circ} \mathrm{C}, \mathrm{pH}=4.66, \mathrm{n}=100 \mathrm{~min}^{-1}$ 
Table 1: Overview of commercially available and prototype screening systems

\begin{tabular}{|c|c|c|c|c|c|}
\hline System/ Ref. & $\begin{array}{l}\text { Volume/Work. } \\
\text { Volume [mL] }\end{array}$ & $\begin{array}{c}\text { Instrumentation/ } \\
\text { Control }\end{array}$ & $\begin{array}{c}\text { Number of } \\
\text { parallel reactors }\end{array}$ & Aeration & $\begin{array}{c}\text { Operational } \\
\text { mode }\end{array}$ \\
\hline \multicolumn{6}{|l|}{ Shake Flasks } \\
\hline $\begin{array}{c}\text { Sensolux/ } \\
\text { Sartorius AG }\end{array}$ & $125-1000$ & $\mathrm{pH}, \mathrm{DO}$ & 9 & none & Batch \\
\hline $\begin{array}{c}\text { SFR/PreSens } \\
\text { GmbH }\end{array}$ & Up to 1000 & $\mathrm{pH}, \mathrm{DO}$ & 9 & none & Batch \\
\hline [4] & 250 & $\mathrm{~F} / \mathrm{F}$ & 4 & $\begin{array}{c}\text { gas } \\
\text { sparging }\end{array}$ & Fed-batch \\
\hline [5] & $500 / 100$ & $\mathrm{pH}, \mathrm{P} / \mathrm{pH}, \mathrm{F}$ & 9 & none & Fed-batch \\
\hline \multicolumn{6}{|l|}{ Bubble Columns } \\
\hline [6] & $5 / 2$ & $\mathrm{P}, \mathrm{F}$ & 25 & $\begin{array}{c}\text { gas } \\
\text { sparging }\end{array}$ & Fed-batch \\
\hline [7] & $500 / 200$ & $\mathrm{pH}, \mathrm{F} / \mathrm{pH}$ & 12 & $\begin{array}{c}\text { gas } \\
\text { sparging }\end{array}$ & Fed-batch \\
\hline STR & 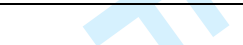 & & & & \\
\hline $\begin{array}{l}\text { Cellstation/ } \\
\text { Fluorometrix }\end{array}$ & 135 & $\mathrm{pH}, \mathrm{DO}, \mathrm{OD} / \mathrm{T}, \mathrm{n}$ & 12 & none & Batch \\
\hline $\begin{array}{c}\text { Xplorer/ } \\
\text { Bioxplore (HEL } \\
\text { Ltd.) }\end{array}$ & $130-100$ & $\begin{array}{c}\mathrm{T}, \mathrm{pH}, \mathrm{DO}, \mathrm{F} / \mathrm{T} \\
\mathrm{pH}, \mathrm{DO}, \mathrm{n}\end{array}$ & 8 & $\begin{array}{l}\text { 4-gas } \\
\text { mixing }\end{array}$ & Fed-batch \\
\hline $\begin{array}{c}\text { Explorer/ } \\
\text { Medicell Oy }\end{array}$ & $/ 100-500$ & $\begin{array}{c}\mathrm{T}, \mathrm{pH}, \mathrm{DO}, \mathrm{OD}, \mathrm{F} / \\
\mathrm{T}, \mathrm{pH}, \mathrm{DO}, \mathrm{n}, \mathrm{F}\end{array}$ & 15 & $\begin{array}{l}\text { 3-gas } \\
\text { mixing }\end{array}$ & Fed-batch \\
\hline $\begin{array}{l}\text { DASGIP AG } \\
\text { Bioblock }\end{array}$ & $/ 150-4000$ & $\begin{array}{c}\text { T, pH, DO, OD, F, } \\
\text { Foam/ T, pH, DO, } \\
\text { n, Foam, F }\end{array}$ & 16 & $\begin{array}{l}\text { 4-gas } \\
\text { mixing }\end{array}$ & Fed-batch \\
\hline $\begin{array}{l}\text { Biostat Qplus } \\
\text { /Sartorius AG }\end{array}$ & $1500-1000$ & $\begin{array}{c}\mathrm{T}, \mathrm{pH}, \mathrm{DO}, \mathrm{F} \\
\text { Foam/ T, pH, DO, } \\
\mathrm{n}, \text { Foam, F }\end{array}$ & 12 & $\begin{array}{l}\text { 4-gas } \\
\text { mixing }\end{array}$ & Fed-batch \\
\hline $\begin{array}{l}\text { Multifors/ Infors } \\
\text { AG }\end{array}$ & $/ 500-1000$ & $\begin{array}{c}\mathrm{T}, \mathrm{pH}, \mathrm{DO}, \mathrm{F}, \\
\text { Foam/ T, pH, DO, } \\
\mathrm{n}, \text { Foam, F }\end{array}$ & 6 & $\begin{array}{l}\text { 4-gas } \\
\text { mixing }\end{array}$ & Fed-batch \\
\hline $\begin{array}{l}\text { Biostat B-DCU- } \\
\text { II/Sartorius AG }\end{array}$ & $\begin{array}{l}/ 500- \\
10000\end{array}$ & $\begin{array}{c}\mathrm{T}, \mathrm{pH}, \mathrm{DO}, \mathrm{F}, \\
\text { Foam/ T, pH, DO, } \\
\mathrm{n}, \text { Foam, F }\end{array}$ & 6 & $\begin{array}{l}\text { 4-gas } \\
\text { mixing }\end{array}$ & Fed-batch \\
\hline [8] & 12 & $\begin{array}{l}\mathrm{pH}, \mathrm{DO}, \mathrm{OD} / \\
\mathrm{DO} \text { (on-off), n }\end{array}$ & 24 & $\begin{array}{c}\text { gas } \\
\text { sparging }\end{array}$ & Batch \\
\hline [9] & $/ 12$ & $\begin{array}{c}\mathrm{T}, \mathrm{pH}, \mathrm{DO}, \mathrm{OD}, \mathrm{F} / \\
\mathrm{T}, \mathrm{pH}, \mathrm{F}, \mathrm{n}\end{array}$ & 48 & $\begin{array}{c}\text { gas } \\
\text { sparging }\end{array}$ & Batch \\
\hline [10] & 130 & $\mathrm{pH}, \mathrm{DO} / \mathrm{T}, \mathrm{n}$ & 12 & $\begin{array}{l}2 \text {-gas } \\
\text { mixing }\end{array}$ & Batch \\
\hline [11] & $/ 100$ & $\begin{array}{c}\text { T, pH, DO, OD, } \\
\text { F/T, n }\end{array}$ & 4 & $\begin{array}{c}\text { gas } \\
\text { sparging }\end{array}$ & Batch \\
\hline
\end{tabular}


Table 2: Overview of commercially available and developed membrane based reactor systems

\begin{tabular}{|c|c|c|c|c|c|}
\hline System/ Ref. & $\begin{array}{c}\text { Work. Volume } \\
{[\mathrm{mL}]}\end{array}$ & $\begin{array}{c}\text { Instrumentation } \\
\text { /Control } \\
\end{array}$ & $\begin{array}{c}\text { Number of } \\
\text { parallel reactors }\end{array}$ & $\begin{array}{c}\text { Number of } \\
\text { Phases/Remark }\end{array}$ & $\begin{array}{c}\text { Operational } \\
\text { mode }\end{array}$ \\
\hline EMR/ JFC GmbH & 10 & $\mathrm{P}$ & 1 & 1 & Continuous \\
\hline $\begin{array}{c}\text { Celline/ } \\
\text { Sartorius AG }\end{array}$ & $350-1000$ & - & 1 & 1/Disposable & Batch \\
\hline [12] & 0,2 & $/ F$ & 1 & 1 & Continuous \\
\hline [13] & 10 & $/ \mathrm{T}, \mathrm{n}$ & 1 & 1 & Continuous \\
\hline [14] & 10 & $/ \mathrm{T}, \mathrm{n}$ & 1 & 1 & Continuous \\
\hline [15] & 18 & $\mathrm{~T}, \mathrm{P}, \mathrm{F} / \mathrm{T}$ & 1 & $\begin{array}{l}\text { 1/High-pressure } \\
\text { reactor }\end{array}$ & Continuous \\
\hline [16] & 25 & $\mathrm{P}, \mathrm{F} / \mathrm{T}, \mathrm{F}$ & 1 & 1/Aerated & Continuous \\
\hline [17] & 40 & $/ \mathrm{T}, \mathrm{n}$ & 1 & $\begin{array}{l}\text { 1/Water sorption } \\
\text { with mol. sieves }\end{array}$ & Batch \\
\hline [15] & 45 & $\mathrm{~T}, \mathrm{P}, \mathrm{F} / \mathrm{T}$ & 1 & $\begin{array}{l}\text { 1/High-pressure } \\
\text { reactor }\end{array}$ & Continuous \\
\hline$[18]$ & 50 & $/ \mathrm{T}, \mathrm{n}$ & 1 & 1 & Continuous \\
\hline [19] & 100 & $/ \mathrm{T}, \mathrm{n}$ & 1 & 2 & Batch \\
\hline [20] & $\sim 60$ & $\mathrm{P} / \mathrm{T}$ & 1 & $\begin{array}{l}2 / \text { Tubular } \\
\text { reactor }\end{array}$ & $\begin{array}{l}\text { Pseudo - } \\
\text { continuous }\end{array}$ \\
\hline [21] & 110 & $/ \mathrm{T}, \mathrm{n}$ & 1 & 1/Pevaporation & Continuous \\
\hline$[22]$ & 120 & $/ \mathrm{T}, \mathrm{n}$ & 1 & $\begin{array}{c}\text { 1/ Pseudo- } \\
\text { homogeneously }\end{array}$ & Continuous \\
\hline [23] & 500 & $/ \mathrm{T}$ & 1 & $\begin{array}{c}\text { 1/Membrane } \\
\text { extraction }\end{array}$ & Continuous \\
\hline [24] & $\sim 600$ & $\mathrm{P} / \mathrm{T}, \mathrm{n}$ & 1 & 1 & Continuous \\
\hline [25] & 600 & $/ \mathrm{T}$ & 1 & 1 & Continuous \\
\hline [26] & 600 & $\mathrm{P} / \mathrm{T}, \mathrm{pH}$ & 1 & 2 & Batch \\
\hline [27] & 1500 & $\mathrm{~T}, \mathrm{~F} / \mathrm{T}, \mathrm{pH}$ & 1 & 1 & Continuous \\
\hline [28] & 2500 & $\mathrm{~T}, \mathrm{pH}, \mathrm{F} / \mathrm{T}, \mathrm{n}$ & 1 & $\begin{array}{c}\text { 2/El. membrane } \\
\text { cleaning }\end{array}$ & $\begin{array}{l}\text { Pseudo- } \\
\text { continuous }\end{array}$ \\
\hline
\end{tabular}




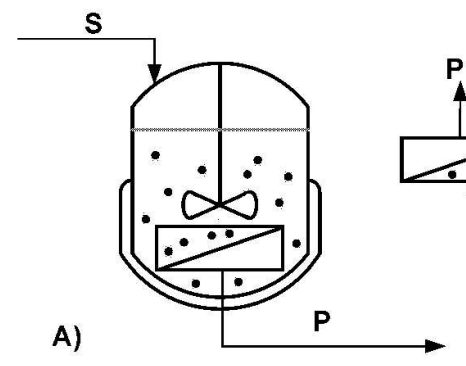

E)

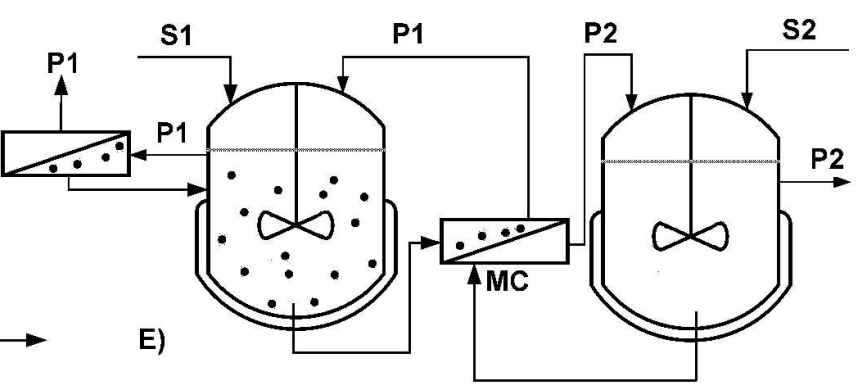

B)

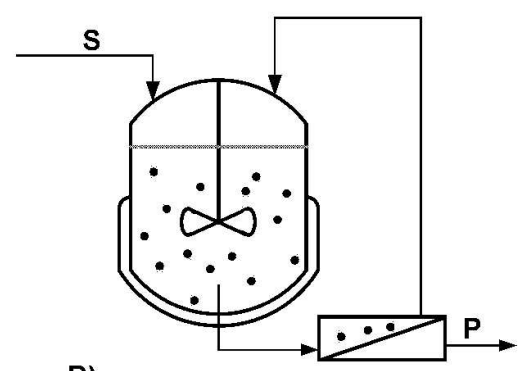

D)
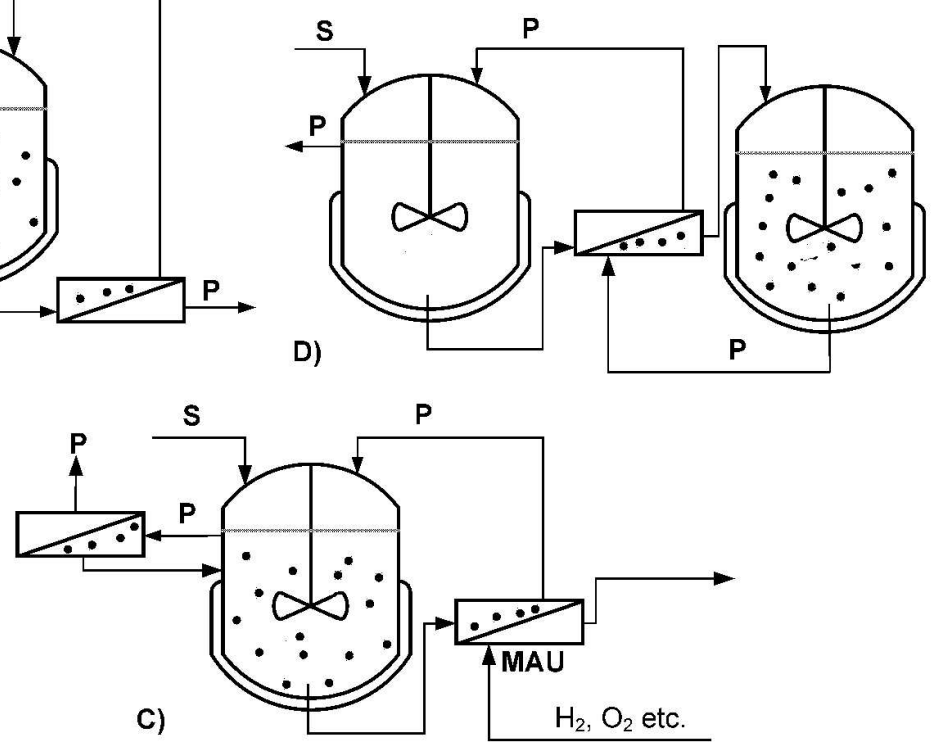

Figure 1: MCSTR configurations: A) with direct S-E contact and in-situ filtration; B) with direct S-E contact and external filtration; C) with direct S-E contact and membrane aeration; D) MCSTR with indirect S-E contact and external filtration (dialysis); E) two-phase MCSTR with external circulation (membrane contactor); •: enzyme; S: substrate; P: product; MC: Membrane Contactor; MAU: Membrane Aeration Unit 


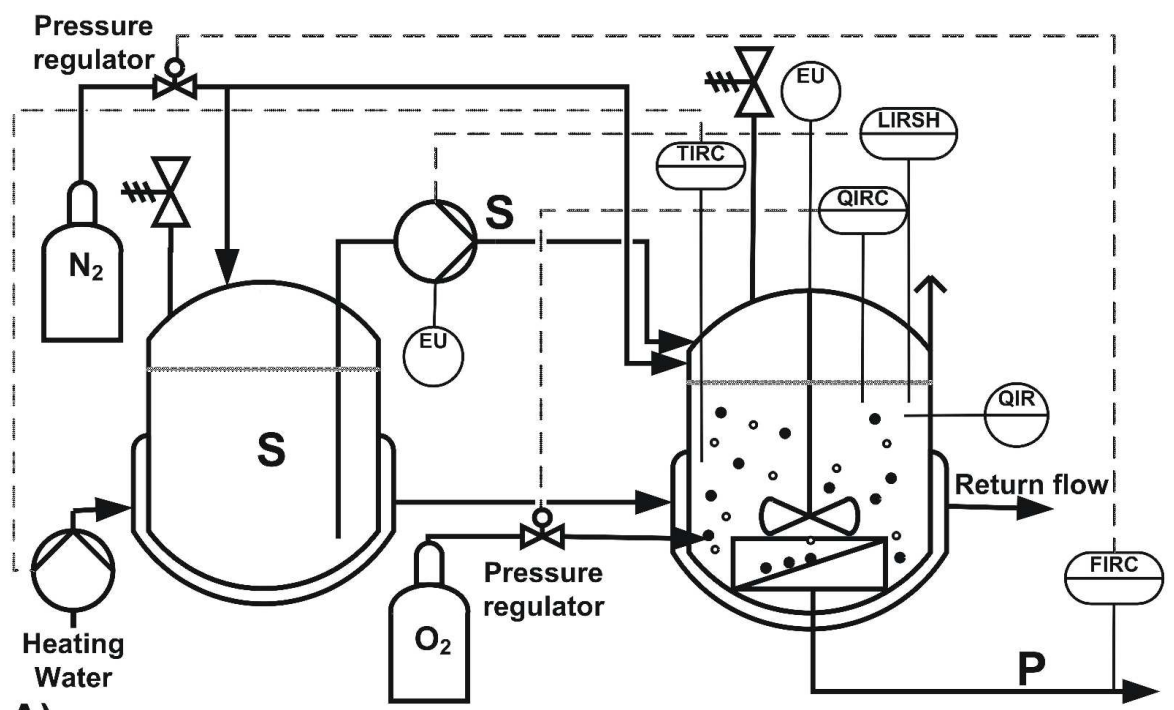

A)

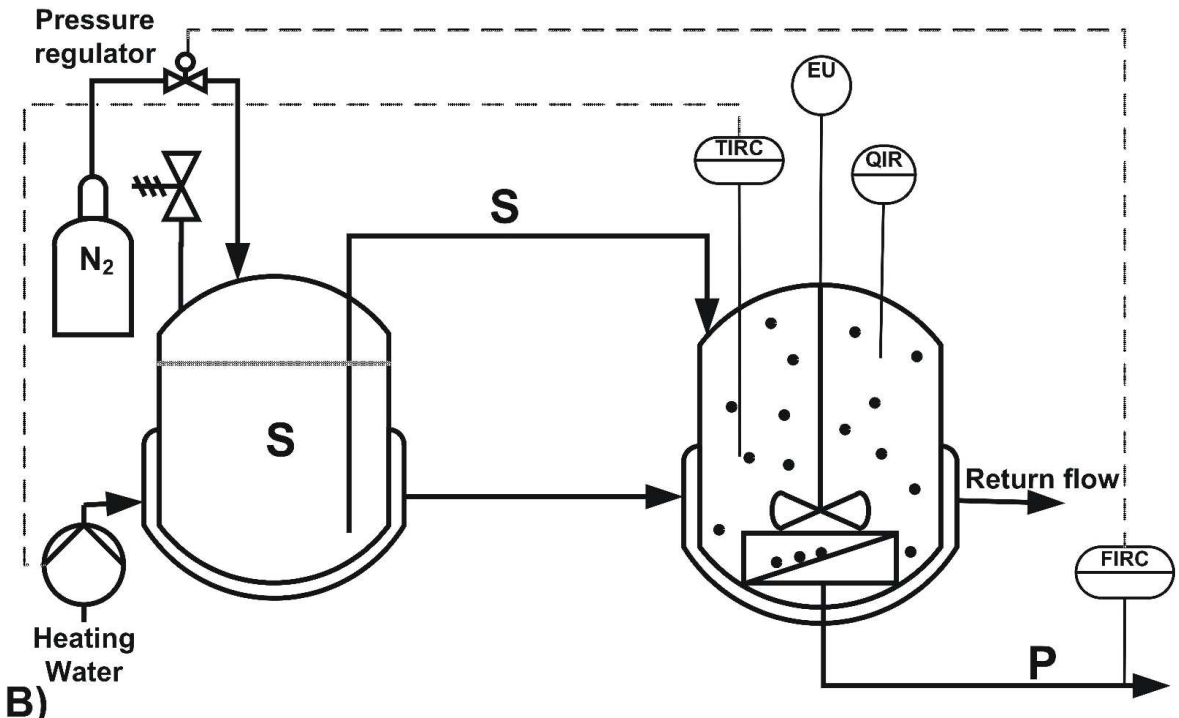

Figure 2: In-situ MCSTR concepts: A) with oxygen supply; B) without oxygen supply; • enzymes; ○ gas bubbles; S: substrate; P: product $852 \times 1129 \mathrm{~mm}$ ( $144 \times 144$ DPI) 
Figure 3: Suggested reaction mechanism of cellulose hydrolysis with a cellulase complex; $\mathrm{C}$ : Exocellulase; CX: Endocellulase (adapted from [33])

$$
116 \times 62 \mathrm{~mm}(600 \times 600 \mathrm{DPI})
$$




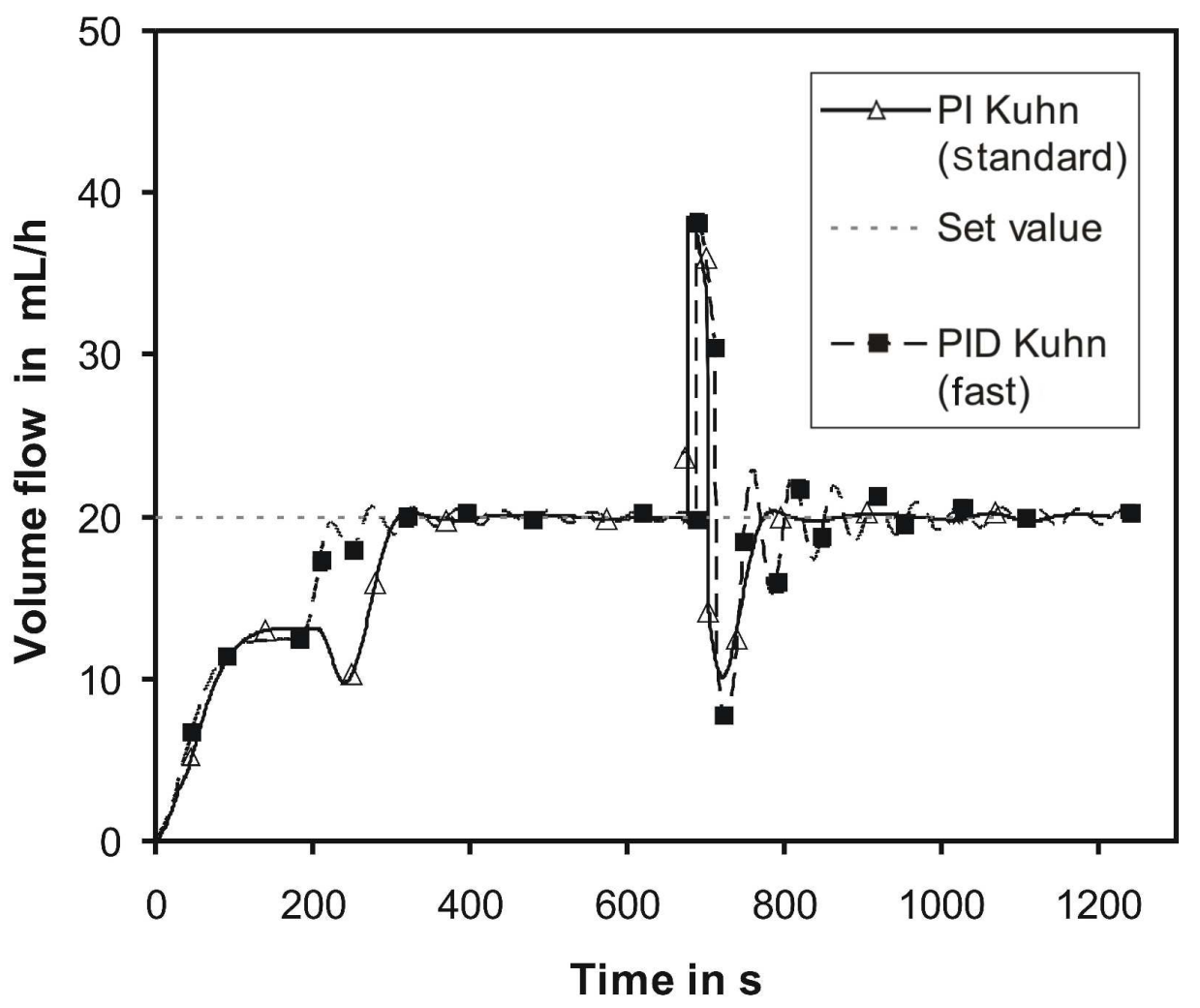

Figure 4: Example of a step response: PI and PID controller acc. to Kuhn [38], set value and disturbance behaviour for different controller settings $913 \times 765 \mathrm{~mm}(144 \times 144 \mathrm{DPI})$ 


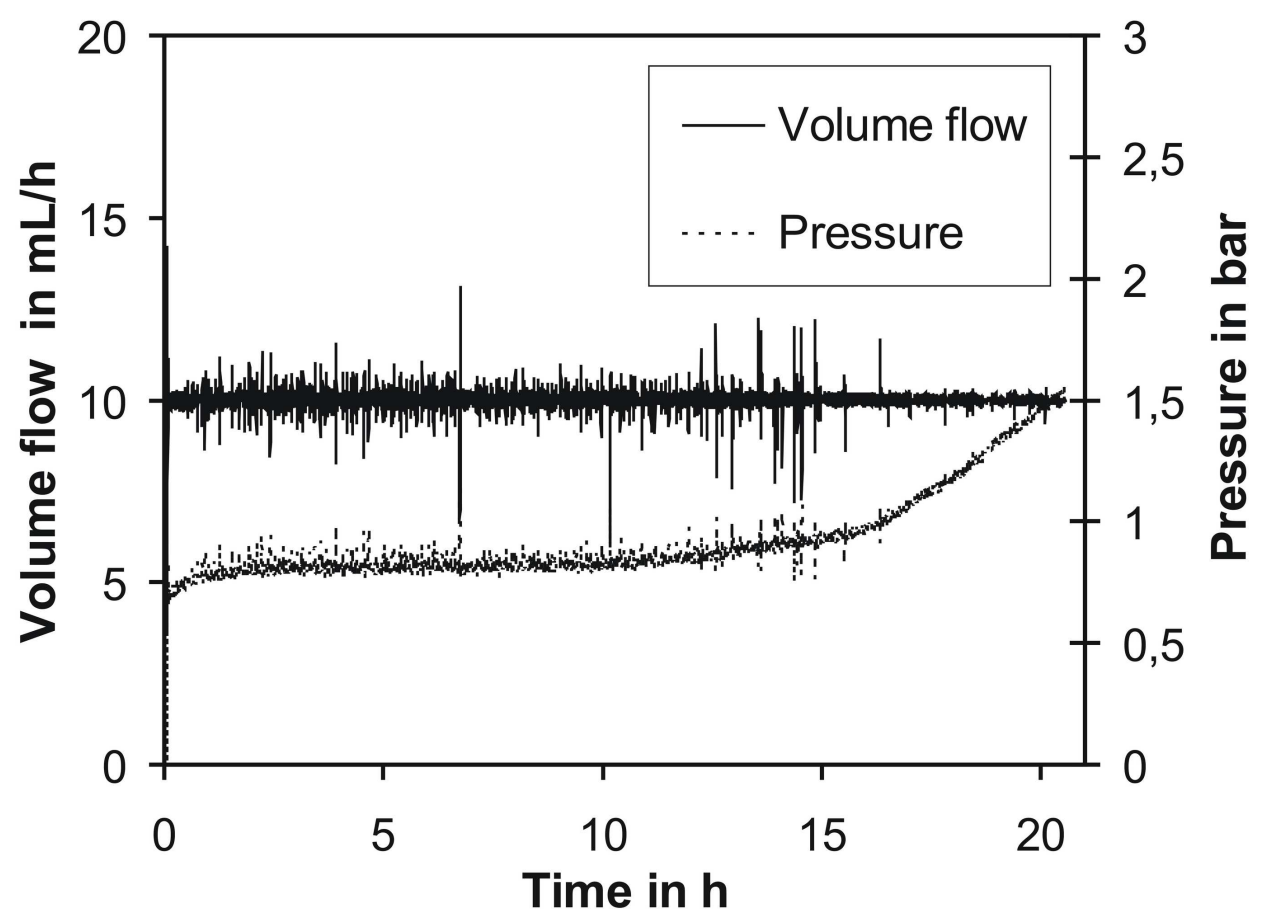

Figure 5: Volumetric flow rate and retentate pressure development, $\mathrm{cS}, 0=25 \mathrm{~g} / \mathrm{L}, \mathrm{T}=40{ }^{\circ} \mathrm{C}(\mathrm{PI}$ controller acc. to Kuhn [38]) $122 \times 89 \mathrm{~mm}(600 \times 600 \mathrm{DPI})$ 


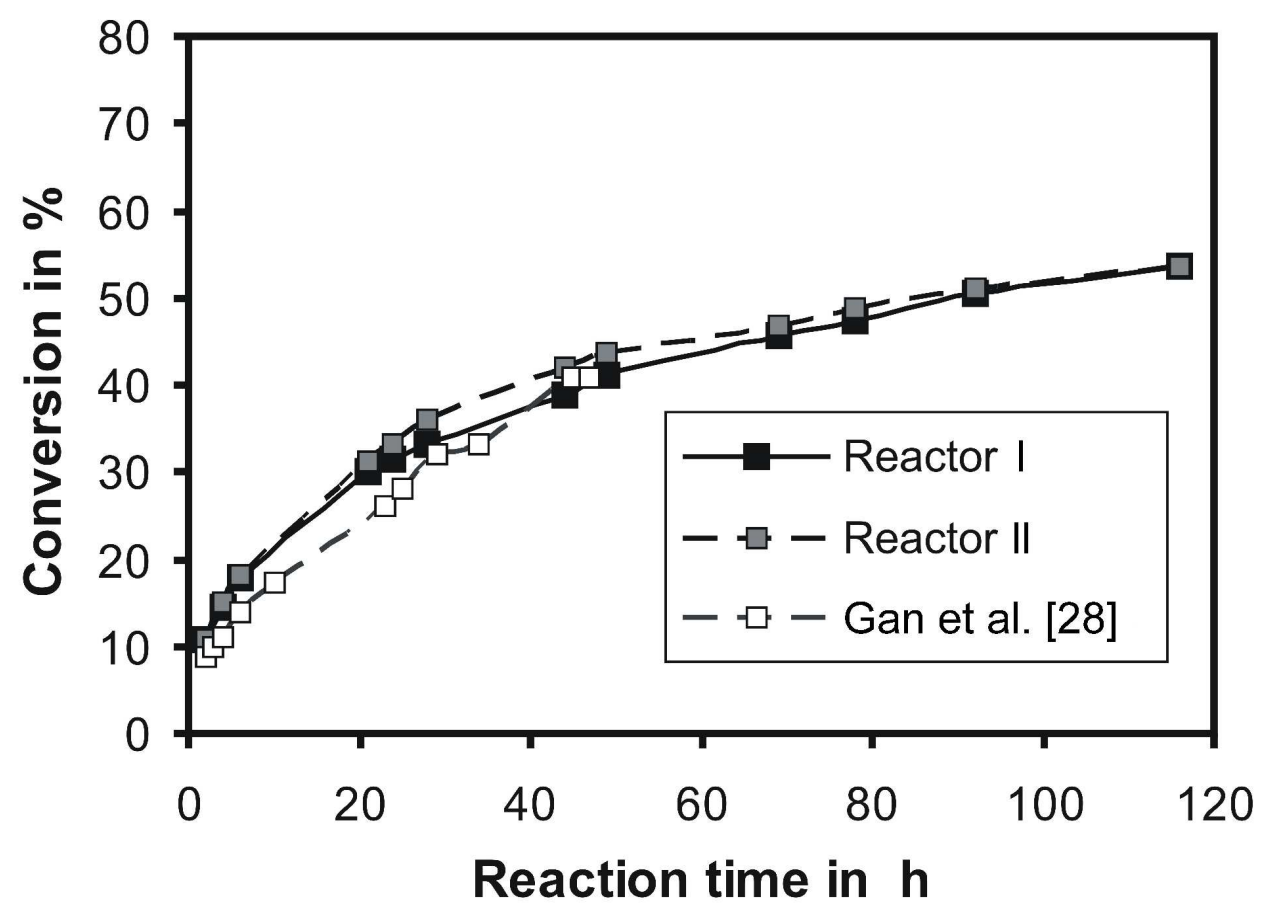

Figure 6: Cellulose conversion during parallel batch runs, $c E=1120 \mathrm{U} / \mathrm{L}, \mathrm{CS}, 0=25 \mathrm{~g} / \mathrm{L}, \mathrm{T}=6 \mathrm{~h}, \mathrm{~T}$ $=40^{\circ} \mathrm{C}, \mathrm{pH}=4.66, \mathrm{n}=100 \mathrm{~min}-1$ $1048 \times 775 \mathrm{~mm}(144 \times 144 \mathrm{DPI})$ 


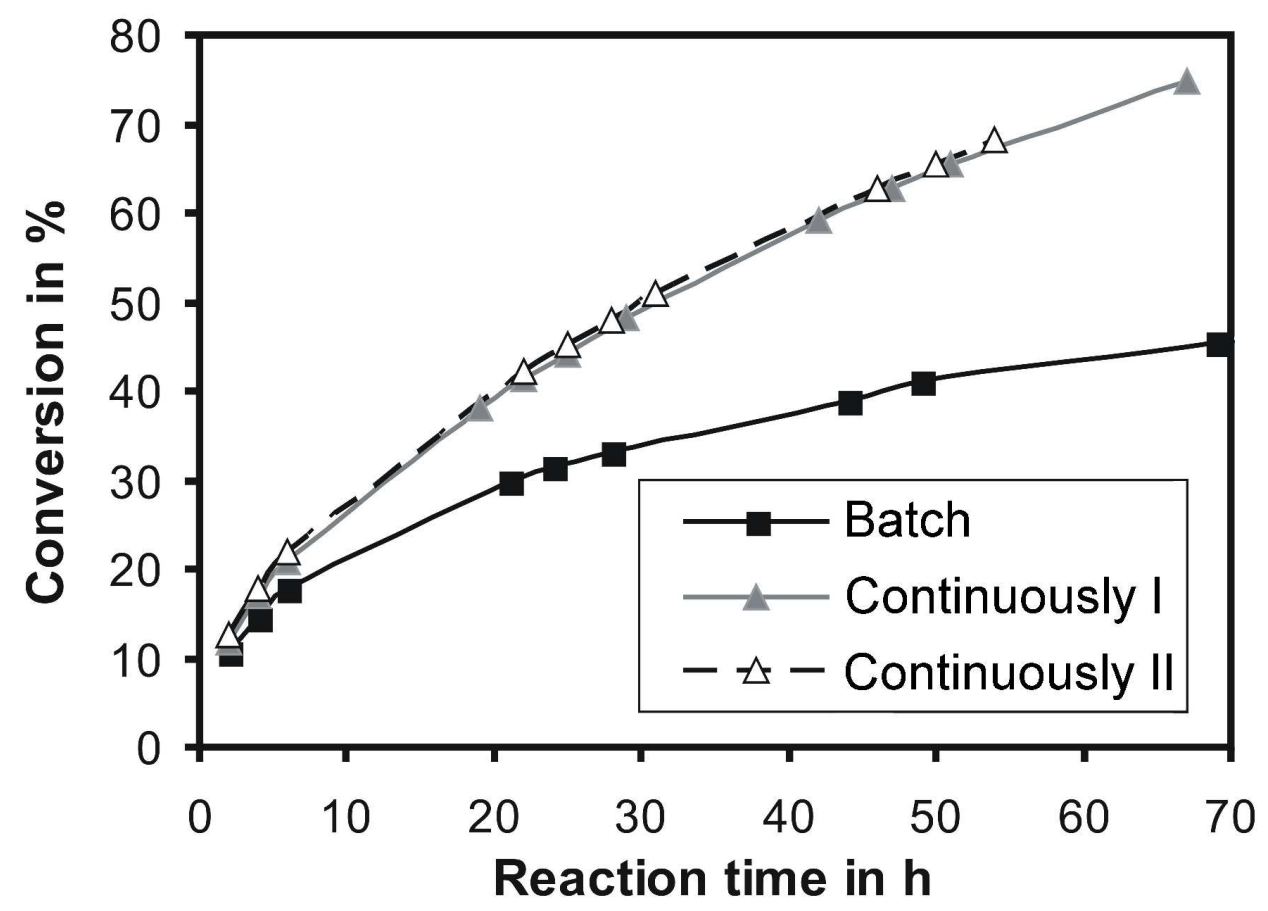

Figure 7: Cellulose conversion during batch and continuous operation, $c E=1120 \mathrm{U} / \mathrm{L}, \mathrm{CS}, 0=25$ $\mathrm{g} / \mathrm{L}, \mathrm{T}=6 \mathrm{~h}, \mathrm{~T}=40^{\circ} \mathrm{C}, \mathrm{pH}=4.66, \mathrm{n}=100 \mathrm{~min}-1$ $652 \times 486 \mathrm{~mm}(144 \times 144 \mathrm{DPI})$ 


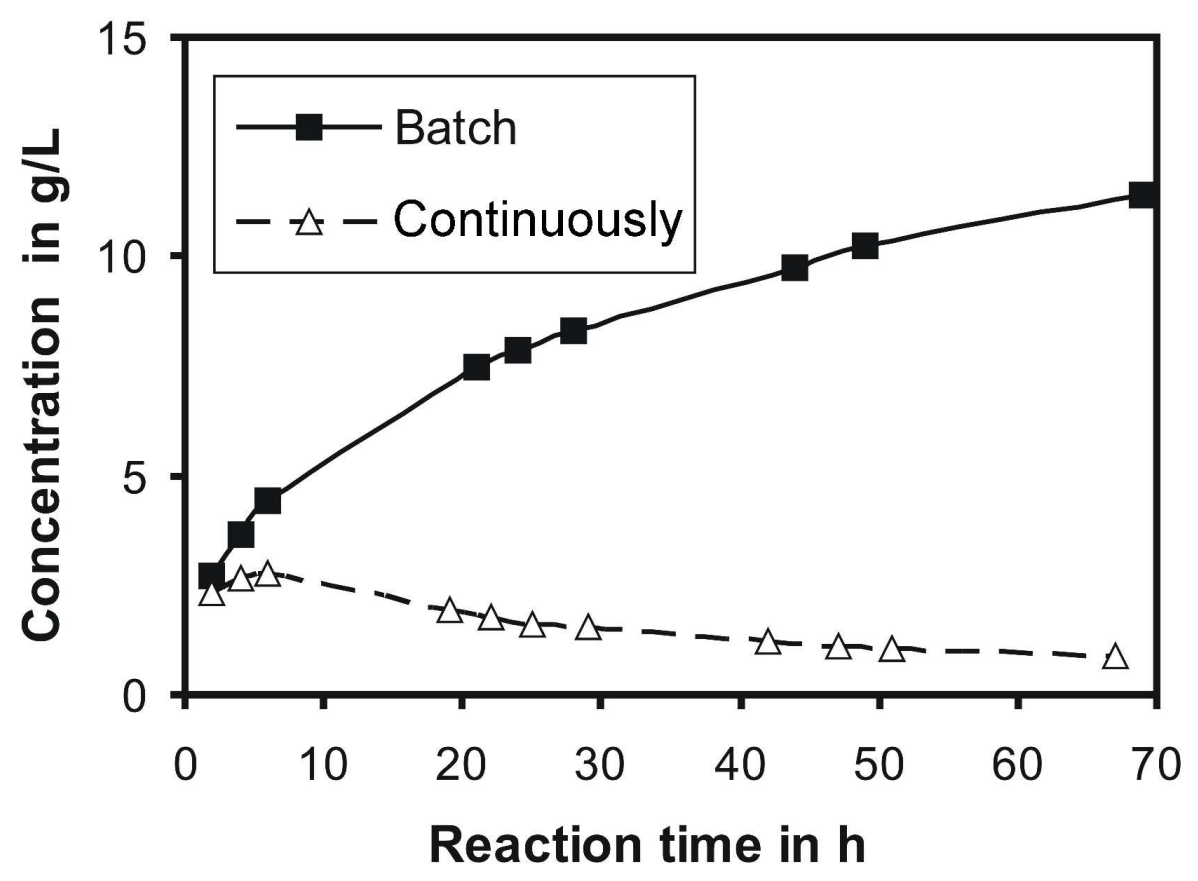

Figure 8: Concentration profile for products (glucose and cellobiose) during batch and continuous operation, $\mathrm{CE}=1120 \mathrm{U} / \mathrm{L}, \mathrm{CS}, 0=25 \mathrm{~g} / \mathrm{L}, \mathrm{T}=6 \mathrm{~h}, \mathrm{~T}=40^{\circ} \mathrm{C}, \mathrm{pH}=4.66, \mathrm{n}=100 \mathrm{~min}-1$ $654 \times 483 \mathrm{~mm}(144 \times 144 \mathrm{DPI})$ 